\title{
Impact of Going-Concern Audit Opinion on Cost of Equity with Institutional Ownership as Moderation
}

\author{
Deriqqa Mawaddah Yulfa \\ Department of Accounting, Faculty Economic and Business \\ Universitas Indonesia Depok, \\ Indonesia \\ deriqqa.mawaddah@gmail.com
}

\author{
F Fitriany \\ Department of Accounting, Faculty Economic and Business \\ Universitas Indonesia \\ Depok, Indonesia \\ fitri_any@yahoo.com
}

\begin{abstract}
This study aims to examine whether goingconcern audit opinion and institutional ownership measured by the percentage of institutional ownership affect the cost of equity, and whether institutional ownership moderates the impact of going-concern audit opinion on cost of equity. From regression using a 1.428 annual report from 2011-2016, with a capital asset pricing model method to measure the cost of equity, this study found a positive relationship between goingconcern audit opinion and the cost of equity, that is, if the company receives a going-concern audit opinion, the cost of equity will increase. Going-concern audit opinion reflects risks to the company, thereby increasing the company's cost of equity. This research also finds that institutional ownership has a negative impact on cost of equity; thus, the higher the percentage of institutional ownership in a firm, the lower the company's cost of equity. In moderation testing, this study finds that institutional ownership weakens the positive impact of going-concern audit opinion on cost of equity. This can be due to institutional investors monitoring the company's performance; thus, the company can improve its performance in order to minimize the possibility of getting a going-concern audit opinion.
\end{abstract}

Keywords-audit opinion, cost of equity, institutional ownership, investor

\section{INTRODUCTION}

An auditor has a responsibility to maintain the reliability of the quality of financial statements and to assess whether the company's financial statements have been fairly presented. The result of the audit report is an opinion on the fairness of the company's financial report. Auditors must also ascertain whether the company can maintain its business continuity, because business continuity is also a basic assumption in the basic framework of the presentation and preparation of financial statements. The assumption of business continuity is also further stipulated in the International Standard on Auditing No 570 (ISA 570) on business continuity, whereby the auditor must provide an expert opinion in the auditor report if the auditor finds evidence of a firm's persistence in maintaining its business survival.

Implication of ISA 570 warns auditor purposely that if in assessing the company's financial condition the auditor finds evidence of potential doubts that the company cannot maintain its viability, the auditor must submit this information in the independent auditor's report with an explanatory paragraph or emphasis (hereinafter referred to as anonymizing concern) [1].

The obligation of disclosure of a going-concern opinion represents the quality of a company reflected in the provision of a going-concern opinion, and this increases corporate risk. The effect of providing a going-concern opinion can influence the increase of the firm's cost of equity [1]. When investors receive information in the form of a going-concern opinion, these investors assume a potential bankruptcy [1]. To minimize the risk of bankruptcy, investors react by increasing the rate of return that affects the increase in the company's cost of equity. In other words, the higher the level of investment risk that is "distorted" from the giving of going-concern opinion, the higher the cost of equity (equity) that must be borne.

Further, another studies prove that institutional ownership negatively impacts the cost of corporate equity [2]. In addition, institutional investors actively monitor the performance of the firms they invest in, and this type of monitoring can generate a range of benefits for the company, for example the decrease of the company's capital costs [3].

This study aims to continue research conducted by Amin, Krishnan, \& Joon, 2014, pp. 1-39 [1], who examines the influence of going concerns and institutional ownership of cost of equity but modifies some aspects. The main difference between this study and the research of Amin, Krishnan, \& Joon, 2014, pp. 1-39 [1] is that institutional ownership variables are added for moderation testing. Although the number of companies owned by institutional investors is quite low in Indonesia, the relations between audit opinion and institutional ownership are worthwhile of investigation because this topic relates to the positive effect of the audit opinion on the cost of equity and how the presence of institutional ownership can reduce the response. The results of this study are expected to provide the company with a novel perspective to use in deliberations with institutional investors as one of its ownership. Another difference that distinguishes this study from the research of Amin et al., (Amin, Krishnan, \& Joon, 2014, pp. 1-39) [1] is the method of measuring the cost of equity. This research uses the capital asset pricing model (CAPM) method while the research of Amin, Krishnan, \& Joon, 2014, pp. 1-39 [1] using the price earning growth (PEG) ratio method. This study uses the CAPM method because the PEG ratio method cannot be used to measure the cost of equity because this method uses the earnings per share prediction data from the analyst, whereas the condition in Indonesia predictive earnings per share data from the analyst is not available.

The purpose of this study is to examine whether a goingconcern audit opinion positively affects the cost of equity, institutional ownership negatively affects the cost of equity, and institutional ownership weakens the positive effect of going-concern audit opinion on equity costs. This research is 
notable to perform in Indonesia because this research can accommodate the audit standard of a risk-based audit, which was adopted in Indonesia as of January 1, 2013; thus, this research is expected to provide implications for auditors regarding their effort to improve audit quality from the planning through completion phases and be more careful when giving audit opinion.

\section{ANALYTICAL FRAMEWORK}

\section{A. Signaling Theory}

Firms can signal investors through audit practices [4]. Investors have an expectation that audited financial statements have better quality information than unaudited financial statements so that investors would more believe to the information obtained from the audited financial statements than to the unaudited financial statements. The different response from investors is due to an expectation gap audit, that is, the difference between actual audit procedures performed on financial statements and user expectations of financial statements [5]. Investors have expectations that audited financial statements have better information than unaudited financial statements. We referred to the signaling theory in this study because an audit opinion is a statement from an independent external party; thus, it will be an alert to investors to make a decision based on what has been shown in the audited financial statements [4].

\section{B. Audit Opinion and Going-Concern Audit Opinion}

An auditor gives five types of opinion (opinion), including an;unqualified opinion, an unqualified opinion withexplanatory paragraph or modified wordinga qualified opinion, an adverse opinion, and a disclaimer of opinion [6].

The International Standard on Auditing No 570 states that the auditors should mention opinion-related business continuity in the audit report if an auditor finds evidence of a company's doubt in maintaining its business viability. The International Standard on Auditing No 570 provides guidance that the auditors should declare a modification opinion that notices the existence of a material uncertainty related to an event or condition that may cause significant doubt over the entity's ability to sustain its business.

Furthermore, if adequate disclosure of business continuity is not included in the financial statements, the auditor must state a reasonable opinion with an exception or an unfair opinion that emphasizes the material uncertainty that may cause significant doubt over the entity's ability to sustain its business. If the financial statements have been prepared on the basis of business continuity, but according to the auditor's consideration, the use of the business continuity assumption in the financial statements prepared by management is not appropriate, and the auditor must express an unfair opinion.

\section{Institutional Ownership Theory}

Institutional ownership is the ownership of shares of companies owned by institutions or institutions such as insurance companies, banks, investment companies, and other institutional holdings [3]. Institutional ownership is critical because institutional ownership can encourage more optimal oversight. The higher the level of institutional ownership, the greater the oversight of institutional investors in the company. Institutional shareholders with large shareholdings are incentivized to monitor corporate decision making [7].

\section{Impact of a Going-Concern Audit Opinion on Cost of Equity}

The previous research focuses on the scope of cost of equity, and they argue that equity financing is considered more expensive than the cost of debt [1]. Equity financing has a greater risk than debt financing because the investor's expected return on equity financing is greater when compared with the returns that investors receive from debt financing. Because capital funding has a strong influence on investors in the form of expected rate of return, the expectation is that the company can maintain its corporate value by maintaining the quality of financial statements reflected in the audit opinion.

Going-concern audit opinion is a statement from a third party from outside the company stating that the company is doubtful about its business continuity [8]. If the company is doubtful of its business continuity, this indicates that the company is at risk to continue its business, where the risk is attached to the company and this condition is a threat to investors in the company. The going-concern audit opinion provides a signal to investors about the unfavorable condition of the company, to which the investor reacts by requesting a larger return from the company as a guarantee that they will not be harmed by their investment in the company's doubtful business continuity, causing an increase in the company's cost of equity.

Hypothesis 1: Going-concern audit opinion has a positive impact on the cost of equity

\section{E. Impact of Institutional Ownership on Cost of Equity}

Institutional ownership is critical because institutional ownership can encourage more optimal oversight. The higher the degree of institutional ownership the greater the oversight of institutional investors in the company as the institutional shareholders with large shareholdings are incentivized to monitor corporate decision making [7].

Institutional investors actively monitor the performance of the companies they invest in, and this type of monitoring can generate benefits for the company [3]. The institutional investors monitoring actions can actively participate in corporate governance in an effort to protect their investment and corporate value [9].

Institutional investors are judged to have a better ability to read market conditions compared with individual investors. Institutional investors not only play a role in controlling shareholders but also in open information on financial markets because this information affects investors' views on financial markets [9]. This role makes institutional investors be judged to have an understanding of the market situation compared with individual investors.

The ability to read the situation in markets makes institutional investors able to perform their monitoring function properly. With these monitoring actions, institutional investors know the condition of the company directly. If the company is in bad condition or external influences could harm the company, the institutional investors provide a warning to the company as a form of monitoring; thus, the company can directly improve 
performance to minimize the risks that can harm companies both internally and externally. Because the company is required to improve its performance, the company will receive a benefit, such as lower capital costs [3]. In addition, institutional investors have the ability to provide credible information to the market and to compete to create profitable trading opportunities in the market. This capability has the effect of increasing the efficiency of prices in the market and the quality of corporate information and lowering the cost of equity on the other hand. Following this argument, the cost of equity decreases with the presence of institutional investors who invest long term in a company [9].

Hypothesis 2: Institutional ownership has a negative effect on the cost of equity

Institutional investors are judged to have a better ability to read market conditions compared with individual investors. The ability to read the situation in this market makes institutional investors able to perform its monitoring function properly. With this monitoring action, institutional investors can understand the condition of the company. If the company is in bad condition or external influences that could harm the company, the institutional investors warn the company as a form of monitoring; thus, the company can directly improve performance to minimize the risks that can harm companies both internally and externally. The higher level of corporate awareness of the risks to get a goingconcern audit opinion proves the monitoring role of institutional investors because institutional investors can generate a variety of benefits for the company, lower capital costs for instance [3].

The other supervisory role of institutional investors is when institutional investors are aware if a company is in bad financial condition or at high risk if the company continues its business. Institutional investors have large amounts of funds; thus, they can help companies finance their operations. Another supervisory role of institutional investors is actively participating in corporate governance to maintain the stability of the company to maintain the company's goodwill. Those rules reduce the company's risk; thus, the company's cost of equity decreases simultaneously.

Hypothesis 3: Institutional ownership weakens the positive impact of going-concern audit opinion on cost of equity.

\section{RESEARCH METHOD}

\section{A. Sample Selection}

This study uses the population of companies listed on the Indonesia Stock Exchange (IDX) within the period of the research year, 2011-2016. We use the year 2011 as an initial period for this study due to limited data sources; notably, some variables must be measured for 5 years. The financial data this research uses is obtained from Thomson Reuters, Eikon, and financial statements that have been officially published by either related companies or on the IDX website page. Sampling method we use is purposive sampling. Therefore, the selected samples represent qualifying some precise criteria such as nonfinancial companies listed on the IDX in the period 2011-2016, the company is a company listed on the IDX from 2011-2016, the company was not delisting during the year of research, the company had not been suspended in the year of observation, and other necessary data was available.

\section{B. Research Model}

This research model adopts the research model of Amin, Krishnan, \& Joon, 2014, pp. 1-39 [1], but with a modification: the addition of an institutional ownership variable as moderation. The model in this study aims to examine whether a going-concern audit opinion has a positive effect on cost of equity, whether institutional ownership has a negative effect on cost of equity, and whether institutional ownership weakens the positive effect of going-concern audit opinion on cost of equity.

The research model to meet the research objectives is as follows:

$$
\begin{array}{r}
\text { COE }_{\mathrm{i}, \mathrm{t}}=\alpha+\beta_{1} \mathrm{OPINI}_{\mathrm{i}, \mathrm{t}}+\beta_{2} \mathrm{INSTOWN}_{\mathrm{i}, \mathrm{t}}+\beta_{4} \mathrm{LLEV}_{\mathrm{i}, \mathrm{t}}+ \\
\beta_{5} \mathrm{LSIZE}_{\mathrm{i}, \mathrm{t}}+\beta_{6} \mathrm{LBTM}_{\mathrm{i}, \mathrm{t}}+\beta_{7} \mathrm{VAR}_{\mathrm{i}, \mathrm{t}}+\beta_{8} \mathrm{RMSE}_{\mathrm{i}, \mathrm{t}}+\beta_{9} \mathrm{ROI}_{\mathrm{i}, \mathrm{t}}+ \\
\beta_{10} \mathrm{BIG}_{\mathrm{i}, \mathrm{t}}+\varepsilon_{\mathrm{i}, \mathrm{t}}
\end{array}
$$

$$
\mathrm{COE}_{\mathrm{i}, \mathrm{t}}=\alpha+\beta_{1} \mathrm{OPINI}_{\mathrm{i}, \mathrm{t}}+\beta_{2} \mathrm{INSTOWN}_{\mathrm{i}, \mathrm{t}}+
$$

$\beta 3$ OPINI*INSTOWNi,t $+\beta_{4}$ LLEV $_{\mathrm{i}, \mathrm{t}}+\beta_{5} \mathrm{LSIZE}_{\mathrm{i}, \mathrm{t}}+$ $\beta_{6} \mathrm{LBTM}_{\mathrm{i}, \mathrm{t}}+\beta_{7} \mathrm{VAR}_{\mathrm{i}, \mathrm{t}}+\beta_{8} \mathrm{RMSE}_{\mathrm{i}, \mathrm{t}}+\beta_{9} \mathrm{ROI}_{\mathrm{i}, \mathrm{t}}+\beta_{10} \mathrm{BIG}_{\mathrm{i}, \mathrm{t}}+$

$\varepsilon_{\mathrm{i}, \mathrm{t}}$

Explanation:

- COE: the cost of equity (ex ante) on April 1 for each firm $i$ in year $t$ calculated using the CAPM method

- OPINI: category of opinion obtained by company $\mathrm{i}$ in year $\mathrm{t}$

- INSTOWN: percentage of institutional ownership of company $i$ in year $\mathrm{t}$

- OPINI*INSTOWN: multiplication between opinion and percentage of institutional ownership

- LLEV: natural logarithm of firm's leverage in year $t$

- LSIZE: natural logarithm of firm's size in year t

- LBTM: natural logarithm of firm's book-to-market ratio in year $t$

- VAR: earning variability is a variation of a company's profit quality in year $\mathrm{t}$

- RMSE: firm's equity risk in year $\mathrm{t}$

- ROI: firm's return on investment in year $\mathrm{t}$

- BIG4: categories of public accounting firms' used companies in year $\mathrm{t}$

\section{Variable Operationalization}

1) Cost of equity

Measurement of COE (cost of equity) using the CAPM method. The CAPM method using the expected return approach on risky investment depends on three factors: the risk-free rate, market risk premium, and systematic risk of the company (company's market beta). Cost of equity based on the CAPM method is formulated based on the following equation:

$$
R_{E}=R_{f}+\beta_{E} x\left(R_{M}-R_{f}\right)
$$

From the equation, $R_{E}$ is the cost of equity ex ante for each firm per year for 6 years of observation. $R_{f}$ is the expected risk-free return of assets from the market calculated 
using the average annual interest rate of Bank Indonesia Certificates for 6 years of observation. $R_{M}-R_{f}$ is a premium market risk derived from a county risk premium calculated by Aswath Damodaran, available on www.damodaran.com. $\beta_{\mathrm{E}}$ is a company beta (systematic risk) calculated from the regression result between the stock return of the firm and the market return projected by the IDX Composite that is annualized from April 1, $t$ until March 31, $t_{+1}$ using the weekly stock price data available at Yahoo Finance for each of the sample companies.

\section{2) Audit opinion}

Audit opinion in this criterion is a dummy variable, where going-concern opinion is given the value 1 , and nongoing concern opinion is given the value 0 . Criteria of going-concern opinion which given the value 1 in this research are an unqualified audit opinion with emphasizes paragraph that mention about the certainty of the company's business sustainability and a qualified audit opinion. Opinion is not fair (adverse) or a disclaimer is a criterion of goingconcern opinion, but this is not included in this research because companies with an adverse audit opinion and disclaimer are included in the category of suspense (suspend) by the IDX and thus do not to meet the criteria sample.

\section{3) Institutional ownership}

Institutional ownership is measured by using the percentage of institutional ownership, which we divide into insurance companies, banks, investment companies, and mutual and pension funds that can be a majority or minority. The higher the percentage of institutional ownership, the higher the level of supervision by institutional investors over the performance of the company [10]; thus, the ownership of the institution is predicted to be negatively related to the cost of equity, weakening the relationship between the positive impact of going-concern opinion on cost of equity.

\section{4) Log_Leverage (LLEV)}

Leverage is a ratio that describes the ratio of total debt to total equity. High leverage reflects the company's risk, such that the leverage variable is predicted to positively affect the cost of equity [1]. This value is a natural logarithm of the firm's leverage ratio for treatment at a firm and has negative equity value so that data are well distributed.

\section{5) Log_Size (LSIZE)}

Size is the size of the company. Company size is projected using market capitalization. The size of the firm describes the results of the company's performance in a certain period; thus, a higher firm size is predicted to decrease the cost of equity. The size of the firm provides a negative relationship to the cost of equity [1]. This value is a natural logarithm of market capitalization value of the company so that data are well distributed.

\section{6) Variability $(V A R)$}

VAR is the earning variability that measures the quality of earnings. The greater the value of VAR, the lower the quality of the company's profit, which decreasing cost of equity so that VAR positively affects the cost of equity [1]. Low profit quality reflects the low quality of the financial statement information. VAR is measured by the standard deviation of net income before an extraordinary item is divided by total asset over 5 years.

\section{7) Log_Book-to-market ratio (LBTM)}

Book-to-market ratio is measured using the book value of equity divided by market value of equity. Book-to-market ratio is useful to assess if the book value of the company is overvalued or undervalued in the market. If the book value of the company is overvalued in the market, this is a bad condition for the company. Book-to-market ratio is revealed has a positive influence on cost of equity. This value is the natural logarithm of the company's book-to-market ratio for the treatment of companies with negative equity values so that data are well distributed [1].

\section{8) Equity risk (RMSE)}

Equity risk is rated as an inherent risk or is also a risk of litigation in the company and is predicted to be positively related to cost of equity [1]. Equity risk is calculated based on the standard error value of the regression result using the market model. The data used for the regression is weekly stock return with the stock return of IHSG.

\section{9) Return on investment (ROI)}

ROI is the expected rate of return on investment. The higher the ROI, the higher the rate of return, the lower the equity cost [1]. ROI is measured by the total sales deduction by the amount of the company's investment divided by the amount of the firm's investment.

10) Big 4

The Big 4 Public Accounting Firm is considered to provide a good audit quality, that negatively affecting the cost of equity [1]. Companies audited by a Big 4 Public Accounting Firm are valued by 1 , and companies audited by a non-BIG 4 public accounting firm are valued by 0 .

\section{RESUlt AND DisCUSSION}

\section{A. Number of Companies Obtained Going-Concern Audit Opinion}

This study uses the population of companies:listed.in IDX in the range of years of research, 2011-2016, by looking at the number of companies that obtain opinion of goingconcern or nongoing concern. Table 1 discusses the number of opinion obtained by nonfinancial corporations on the IDX during

2011-2016.

TABLE I. TOTAL NUMBER OF FIRM's AUdiT OPINION OBTAINED FROM 2011-2016

\begin{tabular}{lcccccrrr} 
& \multicolumn{9}{c}{ Year } & & \\
Audit Opinion & 2011 & 2012 & 2013 & 2014 & 2015 & 2016 & Total \\
\hline Going-concern & 43 & 48 & 51 & 62 & 65 & 74 & $\mathbf{3 4 3}$ \\
Non going-concern & 195 & 190 & 187 & 176 & 173 & 164 & $\mathbf{1 . 0 8 5}$ \\
\hline Total & $\mathbf{2 3 8}$ & $\mathbf{2 3 8}$ & $\mathbf{2 3 8}$ & $\mathbf{2 3 8}$ & $\mathbf{2 3 8}$ & $\mathbf{2 3 8}$ & $\mathbf{1 . 4 2 8}$ \\
\hline
\end{tabular}




\section{B. Descriptive Statistics}

We use descriptive statistics, including the minimum value, maximum value, mean value, and standard deviation (Table 2), to assess the characteristics of each variable in the research model.

The dependent variable, COE, has an average value that amounted to 0.099 with standard deviation amounted to 0.059 . The highest cost of equity value is 0,252 and the lowest cost of equity is 0.040 . The independent variable of a going-concern audit opinion is a dummy variable represented in percentage form. The percentage of firms receiving a going-concern category opinion during the year 2011-2016 was $0.24 \%$, and the percentage who received a nontakeconcern opinion was $0.76 \%$. The trend of ownership by institutions in Indonesia is clearly low (from a total of 1,428 samples during 2011-2016, companies with institutional ownership $>50 \%$ were at approximately $10 \%-20 \%$ ). The maximum value of the institutional ownership variables is 0.675 ; thus, some firms have $67.5 \%$ of shares owned by institutional investors and a minimum value of 0 , which means there are companies whose shares are not owned by institutional investors.
The big4 control variable is a dummy variable represented in percentage form. The percentage of companies that used the audit services of public accountant firms in the big4 category was $31.2 \%$, and the percentage that used the audit services of nonbig4 public accounting firms was $68.8 \%$ from 2011-2016. Variable Size is company size determined based on market capitalization value. Variable size has a maximum value of $\mathrm{Rp} 335.001 .402 .233$ and a minimum value of Rp 39.600.000.000. Because of the negative value carried out on some initial data, the variables Llev, Lsize, and Lbtm were measured using a natural logarithm to welldistributed data.

\section{Pearson Correlation Test}

A Pearson correlation test is conducted to assess the interrelations between each independent variable with the dependent variable. A correlation value exceeding 0.80 provides an indication of a very strong relationship between these variables and allows for multicollinearity.

Table 3 illustrates that most of variables were uncorrelated to the other variables. We can show in between the variables Opinion and COE, for example, that the Pearson correlation value is at 0.6422 .

TABLE II. DESCRIPTIVE STATISTICS

COE Dependent Variable
$\begin{gathered}\text { Independent Variable } \\ \text { Percentage of insitutional ownership } \\ \text { (InstOwnn) }\end{gathered}$
$\quad$ Moderation
Opinion*InstOwn
$\quad$ Control Variable
Leverage (LLEV)
Company size (LSIZE-in million)
Book to market (LBTM)
Earning Variability (VAR)
Equity Risk (RMSE)
ROI

ROI

\begin{tabular}{l}
\hline Ob \\
\hline 1.428 \\
1.428 \\
1.428 \\
1.428 \\
1.428 \\
1.428 \\
1.428 \\
1.428 \\
1.42
\end{tabular}

Mean

0.099

0.114

0.080

0.813

18.865

0.899

0.040

0.680

0.977

\begin{tabular}{ccc}
\hline Std.Dev & Min & Max \\
\hline 0.054 & 0.040 & 0.252 \\
& & \\
& & \\
0.186 & 0.0000 & 0.675 \\
& & \\
0.181 & 0.000 & 0.626 \\
& & \\
0.551 & 0.057 & 2.322 \\
63.212 & 39.6 & 335.001 \\
0.103 & 0.085 & 1.155 \\
0.204 & 0.002 & 0.594 \\
0.364 & 0.157 & 1.358 \\
0.114 & 0.367 & 1.319 \\
\hline
\end{tabular}


TABLE III. PEARSON CORRELATION RESULT

\begin{tabular}{|c|c|c|c|c|c|c|c|c|c|c|}
\hline Variable & COE & Opini & InstOwn & Llev & Lsize & Lbtm & Var & RMSE & ROI & BIG4 \\
\hline COE & 1 & & & & & & & & & \\
\hline Opini & $0,6422 *$ & 1 & & & & & & & & \\
\hline InstOwn & 0,00 & 0,039 & 1 & & & & & & & \\
\hline Opini* InstOwn & $-0,016$ & 0,026 & 0,893 & 1 & & & & & & \\
\hline Llev & 0,127 & $0,185^{*}$ & $-0,083^{*}$ & 1 & & & & & & \\
\hline Lsize & $-0,004$ & $-0,022$ & $-0,133$ & $0,017^{*}$ & 1 & & & & & \\
\hline Lbtm & $0,1314^{*}$ & $0,2109^{*}$ & $-0,040$ & 0,138 & 0,349 & 1 & & & & \\
\hline Var & $0,1399^{*}$ & $0,3119^{*}$ & $0,0951^{*}$ & $-0,0034$ & 0,023 & 0,058 & 1 & & & \\
\hline RMSE & $0,05^{*}$ & 0,007 & $-0,013$ & $-0,006$ & 0,016 & $-0,014$ & 0,024 & 1 & & \\
\hline ROI & $0,042 *$ & $0,0652 *$ & $0,0363 *$ & 0,008 & $-0,024$ & $-0,027$ & 0,084 & $-0,013$ & 1 & \\
\hline BIG4 & 0,003 & 0,049 & $0,7383^{*}$ & $-0,048^{*}$ & $-0,075$ & $-0,001$ & 0,061 & 0,003 & 0,063 & 1 \\
\hline
\end{tabular}

There is only multicollinearity in the interaction of moderation variable Opinion*Instown, which amounted to 0.893 (more than 0.8). However, if there is multicollinearity in the moderated variable, multicollinearity may be ignored. Additionally, the Pearson correlation value interprets the relation between a variable to another variable in the initial stage. For example, the Pearson correlation value between the variable Llev and $\mathrm{COE}$ is 0.127 . This positive value indicates that leverage has a positive response to cost of equity. The Pearson correlation value between the variable Lsize and COE is -0.004; thus, this negative value interprets that a company's size has a negative response to cost of equity. This interpretation, however, cannot be interpreted equally for other variables because there are other steps to examine the hypothesis.

D. Regression Test Results
Opinion has a significant influence with its positive coefficients on COE, and this indicates that going-concern audit opinion has a positive influence on cost of equity. If the firm receives a going-concern audit opinion over a particular period (t) financial report, the firm's equity cost increase immediately, meaning the investor reacts by requesting a higher rate of return to protect their investment in the company receiving the going-concern audit opinion. The reaction of investors is a natural occurrence because funding with capital (equity financing) is considered more expensive compared with funding with debt (cost of debt). Equity financing has a greater risk than debt financing because the investor's expected return on equity financing is greater when compared with the returns that investors receive from debt financing.

Because capital funding has a strong influence on investors in the form of expected rate of return, we expected

TABLE IV. REGRESSION RESULT

\begin{tabular}{|c|c|c|c|c|c|c|c|}
\hline \multicolumn{8}{|c|}{ Regression Tèst Results } \\
\hline \multirow{3}{*}{ Variable } & \multicolumn{3}{|c|}{ No Moderation } & \multicolumn{4}{|c|}{ No Moderation } \\
\hline & \multirow{2}{*}{ Prediction } & \multicolumn{2}{|c|}{ COE } & \multirow{2}{*}{ Variable } & \multirow{2}{*}{ Prediction } & \multicolumn{2}{|r|}{ COE } \\
\hline & & Coef & $\mathbf{P}(z$-test $)$ & & & Coef & $\mathbf{P}(\mathrm{z}$-test $)$ \\
\hline Opini & $(+)$ & 0.129 & $0.002 * * *$ & Opini & $(+)$ & 0.129 & $0.002 * * *$ \\
\hline InstOwn & $(-)$ & -0.058 & $0.068 *$ & InstOwn & $(-)$ & -0.053 & $0.071 *$ \\
\hline Opini*InstOwn & & & & Opini*InstOwn & $(-)$ & 0.022 & $0.011 *$ \\
\hline LLEV & $(+)$ & 0.002 & 0.709 & LLEV & $(+)$ & 0.002 & 0.707 \\
\hline LSIZE & $(-)$ & -0.201 & $0.009 * * *$ & LSIZE & $(-)$ & -0.198 & $0.010 * * *$ \\
\hline LBTM & $(+)$ & 0.003 & $0.059^{*}$ & LBTM & $(+)$ & 0.003 & $0.060 *$ \\
\hline VAR & $(+)$ & 0.018 & 0.378 & VAR & $(+)$ & 0.018 & 0.378 \\
\hline RMSE & $(+)$ & 0.003 & 0.282 & RMSE & $(+)$ & 0.000 & 0.285 \\
\hline ROI & $(-)$ & 0.000 & 0.801 & ROI & $(-)$ & 0.000 & 0.822 \\
\hline Big4 & $(-)$ & 0.000 & 0.978 & Big4 & $(-)$ & -0.005 & 0.608 \\
\hline Constant & & 0.072 & 0.0000 & Constant & & 0.072 & 0.0000 \\
\hline Prob $>F$ & & & & Prob $>F$ & & & 0.000 \\
\hline R-sq & & & & R-sq & & & 0.079 \\
\hline $\mathrm{N}$ & & & & $\mathrm{N}$ & & & 1.428 \\
\hline
\end{tabular}

Table 4 describes the regression results before moderation and after moderation. The test results on the research model before the moderation show that the $\mathrm{p}$ value or $\mathrm{F}$ stat is 0.000 , which is less than $1 \%$ alpha; thus, the research model is fit for this research. The results of the test on the research model after moderation did not show significant changes in $p$ value or $\mathrm{F}$ stat and $\mathrm{R}$ square; thus, the $\mathrm{p}$ value and $\mathrm{R}$-square values in the research model after the moderation testing were similar to the research model before testing moderation. management behavior and encourage management to focus more on the company's performance.

Institutional investors are judged to have a better ability to read market conditions compared with individual investors. The ability to read the situation in this market makes institutional investors perform their monitoring function well. With monitoring actions, institutional investors can understand the condition of the company directly. If the company is in bad condition or external influences that could harm the company, the institutional investors warn the 
company as a form of monitoring; thus, the company can directly improve performance to minimize the risks that can harm companies both internally and externally.

Because the company is required to improve its performance to minimize corporate risk, the company will benefit from lower capital costs [3]. With institutional investors, companies become more profitable because the role of oversight from institutional investors can lower the cost of equity. The final result for hypothesis 2 is accepted, that is, institutional investor ownership negatively affects the cost of equity [2].

The test results after moderation are shown in the multiplication of audit opinion variables and institutional ownership variables. The multiplication result of the two variables, shown as Opinion* in table 4, shows a significant negative effect on cost of equity. The significant negative effect proves that institutional investor ownership weakens the positive effect of going-concern audit opinion on cost of equity: As the proportion of institutional ownership in a company increases, the company's performance results in more overseeing and control to improve the company's performance. In addition, institutional investors have large amounts of funds that can help finance companies in poor financial conditions, to minimize the risk that firms receive going-concern audit opinion and other impacts that lower the cost of equity. The final result for hypothesis 3 is accepted, institutional ownership was proven to weaken the positive effect of going-concern audit opinion on equity costs.

Control variables LLEV, VAR, RMSE, ROI, and Big4 have no significant effect on cost of equity. This result is well illustrated in the research model prior to moderation testing and after moderation testing. The other variable control, the company size, has a significant negative influence on cost of equity, and book-to-market ratio has a significant positive effect on cost of equity.

\section{CONCLUSION AND IMPLICATION}

\section{A. Conclusion}

The results of this study indicate that the audit opinion going-concern has a positive effect on COE. When the company receives a going-concern audit opinion, cost of equity also increases because the going-concern audit opinion describes the risks for the company. such that investors want a high rate of return to continue their investment. The results also satisfy the signaling theory that is, firms can signal investors through audit practices [4].

In addition, the results of this study found evidence that institutional ownership negatively affects the COE. The higher the percentage of total institutional ownership, the lower the cost of equity. Notably, the results of this study. are consistent with the arguments, that is, institutional investors are judged to have intense capabilities to monitor and oversee opportunistic management actions, resulting in companies benefiting from lower capital costs [3].

This study also found evidence that institutional ownership weakens the positive influence of going-concern audit opinion on cost of equity as the institutional investors could oversee the company's performance that would be impacted on the lower cost of equity.

\section{B. Implication}

The results of this study can provide implications for auditors such that she or he can improve audit quality, because the audit opinion affects the company's cost of equity. Moreover, auditors are expected to have profound knowledge about how to determine or how to assess risk in the phase of audit planning, because through this study, we proved that once the Company is risky, the company's business sustainability and the cost of equity will be impacted directly. To improve the audit quality and to meet the auditor knowledge about assessing risk, one of the solutions is using audit tools to assess risk and audit procedures accurately while conducting audit fieldwork. In addition, this research has implications for companies, investors, and academics. With this research, we expect that a company can improve control or internal control in its management. Additionally, a company can change its traditional operation to be more automatic and be integrated with a system, for example, for a private transportation-based firm, they could enhance their business if they want to join with governance to adapt an integrated transportation system instead of managing it by itself. In addition, this research can be a reference for companies to find funding sourced from institutional investors because the institutional investors that oversee the performance of the company have been proven to lower the cost of corporate equity.

From the investor perspective, this research provides implications for information for investors, especially institutional investors, that is, that their role is sufficiently large to oversee the company's performance in minimizing the risk of the company in terms of business continuity. For academic research, we expect that in further research, other proxies can be applied, for example, the institutional ownership proxy used in this study can be replaced with ultimate ownership or family ownership.

\section{Limitations and Suggestions for Further Research}

This study has several limitations. The first limitation was that the method we used to calculate the cost of equity was the CAPM method. The best cost equity measurement method is the PEG ratio [11]; thus, we expect further research to use the PEG ratio or discounted cash flow method. The second limitation is that this study was limited to an assessment of only the percentage of institutional ownership; thus, further research may modify family ownership or ultimate ownership, or research can be performed by using the institutional investor's horizon proxy. The third limitation was that this research focused on only companies that received a going-concern audit opinion; thus, further research could be modified by using company proxies that receive a going-concern audit opinion and companies with financial difficulties (financial distress), because companies experiencing financial distress are too risky to receive a going-concern audit opinion.

\section{REFERENCES}

[1] Amin, K., Krishnan, J., and Joon S. Y, "Going concern opinion and cost of equity", Auditing: A practice and theory, vol. 30(4), pp. 1-39, 2014

[2] Collins, D., \& Huang, H, "Management entrenchment and the cost of equity capital", Journal of Business Research, vol. 64, pp. 356-362, 2010. 
[3] Sharfman, M.P., and Fernando, C.S, "Enviromental risk management and the cost of capital", Strategic Management Journal, vol. 29, pp. 569-592, 2008.

[4] Kajuter, P., Klassmann, F., and Nienhaus, M, "Do reviews by external auditors improve the information content of interim financial statements?", The International Journal of Accounting, vol. 51(1), 23-50, 2016.

[5[ Humphrey, C.G., Moizer, P., and Turley,W.S, "The audit expectation gap-plus ca change, plus c'est la meme chose?", Critical Perspectives on Accounting, vol. 3, pp. 137-161, 1992.

[6] Arens, A. A., Elder, R. J., and Beasley, M. S, "Auditing and Assurance Services" (14th ed.), Upper Saddle River, NJ: Pearson Education, Inc, 2012.
[7] Lakonishok, J., Shleifer, A., and Robert, W. V, "The impact of institutional trading on stock prices", "Journal of Financial Economics",vol. 32, pp. 23-43, 1992.

[8] Rogers, J. L., Skinner, D. J., and Buskirk, A. V, "Earnings guidance and market uncertainty", Journal of Accounting and Economics, vol 48(1), pp. 90-109, 2009.

[9] Attig, N., Clearly, S., Ghoul, S. E., and Guedhami, O, "Institutional investment horizons and the cost of equity capital", Financial Management, Summer ed, pp. 441-477, 2013.

[10] Menon, K. and Williams, D. D, "Investor reaction to going concern audit reports", "The Accounting Review", vol. 85(6), pp. 2075-2105, 2010 .

[11] Botosan, C. and Plumlee, M, "Assessing alternative proxies for the expected risk premium", The Accounting Review, vol. 80(1), pp. $21-53,2005$. 